\title{
METODA POSTUPANJA U UPRAVNOM POSTUPKU U ODNOSU NA METODU POSTUPANJA U UPRAVNOM SPORU I SAZNANJA ISTINE O ČINJENICAMA
}

Prof. dr. sc. Boris Ljubanović*

Prof. dr. sc. Dario Đerđa**

\author{
UDK 35.077 .3 \\ https://doi.org/10.30925/zpfsr.42.2.9 \\ Ur.: 17. svibnja 2021. \\ Pr.: 4. srpnja 2021. \\ Pregledni rad
}

\section{Sažetak}

U radu se obrađuju metode postupanja u potrazi za istinom u upravnom postupku i upravnom sporu. U uvodnom dijelu naglašava se kako je zadatak pravne znanosti dati tumačenje pravila Zakona o upravnim sporovima o utvrđivanju činjenica i dokazivanju te se postavlja pitanje pruža li procesna metoda utvrđivanja činjenica u upravnom sporu sucu onu mogućnost saznanja istine koju ima službena osoba u upravnom postupku. Izlaže se o pojmovnom određenju činjenica, činjeničnog stanja, dokazivanja, utvrđivanja činjenica $i$ načela traženja materijalne istine. Slijedi razmatranje pravila o sporu pune jurisdikcije iz Zakona o upravnim sporovima i tumačenje tih pravila $u$ znanstvenim i stručnim radovima. Ujedno se uspoređuju metode postupanja kojima se utvrđuju činjenice u upravnom postupku i u upravnom sporu. $U$ zaključku autori sumiraju rezultate analize ističući kako je Zakon o općem upravnom postupku skup procesnih normi osnovanih na istražnom načelu i u skladu s tim načelom javnopravnom tijelu daje snažne istražne ovlasti. Procesni sustav Zakona o upravnim sporovima teži skladnoj kombinaciji raspravnog $i$ istražnog načela u kojoj sud ima izravne istražne ovlasti. Metoda postupanja prihvaćena u upravnom sporu pruža sudu mogućnost utvrđivanja istine o činjenicama s jednakim stupnjem izvjesnosti koju može dostići javnopravno tijelo propisanom metodom postupanja u upravnom postupku.

Ključne riječi: činjenično stanje; utvrđivanje činjenica; materijalna istina; upravni spor; upravni postupak.

* Dr. sc. Boris Ljubanović, redoviti profesor, Pravni fakultet Sveučilišta J.J. Strossmayer u Osijeku; ljboris@pravos.hr. ORCID: https://orcid.org/0000-0003-3995-9991.

** Dr. sc. Dario Đerđa, redoviti profesor, Sveučilište u Rijeci, Pravni fakultet; dariod@pravri.hr. ORCID: https://orcid.org/0000-0002-1095-1155. 


\section{UVOD}

Prvi hrvatski model upravnog sudovanja preuzet 1991. iz jugoslavenskoga Zakona o upravnim sudovima, uz novele iz 1992., upravni je spor sveo na spor o zakonitosti upravnog akta, dok je spor pune jurisdikcije bio samo iznimno dopušten. Upravni je sud mogao tužbu uvažiti i poništiti upravni akt ili ju odbiti kao neosnovanu. Kada je našao da spor ne može raspraviti na podlozi činjenica utvrđenih u upravnom postupku, osporeni je upravni akt presudom poništavao. Prema tome, Upravni sud imao je primarno kasacijske ovlasti. Reformacijsku odluku kojom bi meritorno riješio upravnu stvar mogao je donijeti samo ako bi našao da se osporeni upravni akt ima poništiti, jer to priroda stvari dopušta, a podatci postupka daju za to pouzdanu osnovu. ${ }^{1}$ Te odredbe nisu bile usuglašene sa standardima konvencijskoga prava na pošteno suđenje, kao ni s acquis communautaire u pogledu prava suda da u svakom sporu utvrđuje činjenično stanje i provede raspravu. ${ }^{2}$

Zato je u sklopu modernizacije i europeizacije hrvatske javne uprave te nastojanja da se ona ustroji i funkcionira poput javnih uprava država zapadnih demokracija, postavljen zahtjev za jačanjem sudskoga nadzora uprave, u prvome redu upravnoga spora kao samostalnoga sudskog postupka, u kojem će upravni sudovi imati ovlast samostalno utvrđivati činjenice na usmenim i javnim raspravama te donositi reformacijske, umjesto dotad prevladavajućih kasacijskih odluka. Može se zaključiti kako su upravo pravila koja se odnose na rješavanje upravnog spora kao spora pune jurisdikcije iz Zakona o upravnim sporovima donesenoga 2010. ${ }^{3}$ srž reforme hrvatskoga upravnog sudovanja. Ta su pravila u pravnoj literaturi ocijenjena iznimno pozitivno, jer služe jačanju zaštite građana i drugih subjekata, ali i zaštite javnog interesa u ustrojstvu upravnog spora. No, nakon što je važeći Zakon o upravnim sporovima stupio na snagu 1. siječnja 2012., njegova se pravila tumače i na način kojim se donošenje presude kojom se tužbeni zahtjev usvaja, poništava pojedinačna odluka javnopravnog tijela i rješava upravna stvar (spor pune jurisdikcije) ne afirmira, već se ograničava, što je u suprotnosti sa svrhom recentne reforme upravnog spora u Hrvatskoj. Posebnu pažnju pobuđuje gledište prema kojem se u upravnom sporu ne utvrđuje materijalna istina, već se kao i u parničnom postupku utvrđuje stranačka istina, odnosno, tzv. „modificirana“ stranačka istina (više vidi u poglavlju 3. ovoga rada).

Zadatak je pravne znanosti dati tumačenje pravila Zakona o upravnim sporovima kojima je normirano utvrđivanje činjenica i dokazivanje te dati odgovor na pitanje pruža li sudu u upravnom sporu metoda postupanja kojom se utvrđuje istina o činjenicama (na što se u procesnoj teoriji svodi načelo traženja materijalne istine vidi detaljnije u poglavlju 2. ovoga rada) jednaku mogućnost saznanja istine kojom raspolaže javnopravno tijelo u upravnom postupku?

1 Članak 42. ranije važećega Zakona o upravnim sporovima, Službeni list SFRJ, br. 4/77., 36/77. i Narodne novine, br. 53/91., 9/92., 77/92., 20/10.

2 Dario Đerđa, Upravni spor (Rijeka: Pravni fakultet, 2017.), 2-23.

3 Članak 58. Zakona o upravnim sporovima, Narodne novine, br. 20/10., 143/12., 152/14., 94/16., $29 / 17$. 


\section{O POJMOVNOM ODREĐENJU ČINJENICA, ČINJENIČNOGA STANJA, DOKAZIVANJA, UTVR円IVANJA ČINJENICA, ISTINE I NAČELA TRAŽENJA MATERIJALNE ISTINE}

Obrada teme o metodama (načinima) saznanja istine svodi se na analizu postupovnih normi o utvrđivanju činjenica. $\mathrm{Na}$ tu se konstataciju nadovezuje pitanje pojmovnog određenja činjenica, činjeničnog stanja, dokazivanja, utvrđivanja činjenica, istine i načela traženja materijalne istine.

Prema ontološkom ili objektivnom gledištu činjenice su pojave u objektivnoj stvarnosti neovisno o našem znanju o tome. To shvaćanje prevladava u pravnoj teoriji. Činjenice kao takve postoje u stvarnosti, a ne u jeziku kao obliku izražavanja. ${ }^{4}$ Činjenice su objektivna stvarnost, ono što jest neovisno o ljudskom saznanju. ${ }^{5}$ Činjenice su pojave u stvarnosti u kojima se sastaju uvjeti materijalnog kaznenog prava za primjenu kaznene sankcije u konkretnom slučaju i uvjeti procesnog prava za vođenje kaznenog postupka. ${ }^{6}$ Krapac govori o materijalnopravno i procesnopravno relevantnim činjenicama kao pojavama u stvarnosti. ${ }^{7}$ Činjenice su pojave u stvarnosti o čijem pravilu utvrđivanja ovisi donošenje pravilne odluke. ${ }^{8}$ Po gnoseološkom gledištu činjenice nisu sve pojave u objektivnoj stvarnosti, već samo one koje je čovjek misaono - čulno saznao i spoznao, odnosno u postupku samo ono što je procesno tijelo utvrdilo da postoji. Prema Vodineliću nepoznata stvarnost se ne može smatrati činjenicom, jer se „o njoj ne može ništa reći, ne postoji nikakvo znanje o tome“, stoga „fakt je gnoseološka kategorija, korelativna sa spoznajom“. 9 Na gnoseološko shvaćanje nailazimo i u teoriji opće logike, gdje je Šešić ustvrdio kako je „činjenica misaono - čulnom djelatnošću utvrđeno objektivno - realno postojanje izvjesne stvari, pojave, procesa, događanja, osobine ili odnosa“. ${ }^{10} \mathrm{~S}$ druge strane, činjenično stanje skup je činjenica na kojima se temelji primjena pravnih normi. Bayer govori o pravno relevantnom činjeničnom stanju kao skupu pravno relevantnih činjenica na koje sud primjenjuje pravne propise. ${ }^{11}$

U pravnoj teoriji pojmovi dokazivanje i utvrđivanje činjenica u pravilu su sinonimi, jer imaju isto značenje - utvrditi postoji li neka činjenica ili ona ne postoji. Prema Bayerovom mišljenju, dokazivanje je uži pojam, jer označava upotrebu dokaza radi utvrđivanja činjenica, a činjenice se mogu utvrditi dokazima, ali i vlastitim

4 Geoffrey Marshal, „Provisional Concept and Definitions of Fact“, Law and philosophy 18, br. 5 (1999): 447-448.

5 Siniša Triva i Mihajlo Dika, Građansko parnično procesno pravo (Zagreb: Narodne novine, 2004.), 159.

6 Vladimir Bayer, Kazneno procesno pravo: odabrana poglavlja. Knjiga I. Uvod u teoriju kaznenog procesnog prava (Zagreb: Ministarstvo unutarnjih poslova, 1995.), 165.

7 Davor Krapac et al., Kazneno procesno pravo. Prva knjiga: Institucije (Zagreb: Narodne novine, 2020.), 407-408.

8 Vanja Bajović, O činjenicama i istini u krivičnom postupku (Beograd: Pravni fakultet, 2015.), 20.

9 Vladimir Vodinelić, „Problematika činjenica u dokaznoj teoriji krivičnog procesnog prava“, Anali Pravnog fakulteta u Beogradu 40, br. 5 (1992): 371, 373.

10 Bogdan Šešić, Logika i naučna metodologija (Beograd: Naučna knjiga, 1962.), 620.

11 Bayer, Kazneno procesno pravo, 167. 
opažanjem koje, po njegovu stajalištu nije dokaz. ${ }^{12}$

$\mathrm{U}$ svezi s pojmom istine, prema teoriji korespondencije istina je suglasnost subjektivne spoznaje s objektivnom stvarnošću. Shvaćanje po kojemu se takva „potpuna istina“ utvrđuje u pravno normiranim postupcima u pravnoj teoriji uglavnom je napušteno. Prevladava gledište kako istina koja se utvrđuje u postupcima ima relativni karakter. Najveći stupanj izvjesnosti do kojega procesno tijelo može doći je ,materijalna istina“. Prema teoriji konsenzusa, koja prevladava u angloameričkom modelu postupka, istina je ono što se sazna nakon provedenoga pravičnog postupka u kojem se svakoj strani pružaju jednaki izgledi za uspjeh. Bez obzira na teoriju kojoj se zakonodavac priklanja, važan je izbor metode utvrđivanja istine kojom se oblikuje uvjerljiva činjenična osnova presude..$^{13}$ Načelo traženja materijalne istine označava metodu postupanja kojom se dolazi do istinita (pravilna) utvrđivanja činjeničnog stanja, koje predstavlja činjenično stanje na kojem procesno tijelo legitimno osniva svoju odluku. ${ }^{14}$

\section{O PRAVILIMA RELEVANTNIM ZA SPOR PUNE JURISDIKCIJE I NJIHOVU TUMAČENJU}

Prema Zakonu o upravnim sporovima, ako sud utvrdi da je pojedinačna odluka javnopravnog tijela nezakonita, presudom će usvojiti tužbeni zahtjev, poništiti pobijanu odluku i sam riješiti stvar, osim ako to ne može učiniti s obzirom na prirodu stvari ili je tuženik rješavao po slobodnoj ocjeni. Ujedno, ako sud utvrdi da javnopravno tijelo nije u propisanom roku donijelo pojedinačnu odluku koju je prema propisima trebalo donijeti, presudom će usvojiti tužbeni zahtjev i sam riješiti stvar, osim kada to ne može učiniti s obzirom na prirodu stvari ili je tuženik rješavao po slobodnoj ocjeni. ${ }^{15} \mathrm{U}$ navedenim slučajevima, dakle, sud mora samostalno riješiti stvar i donijeti reformacijsku odluku, a kasacijsku odluku može donijeti jedino iznimno, kada o stvari koja je predmetom spora ne može odlučiti s obzirom na prirodu stvari ili jer je tuženik rješavao primjenom slobodne ocjene.

Prema posebnim pravilima Zakona o upravnim sporovima koja uređuju utvrđivanje činjeničnog stanja i dokaze, sud slobodno ocjenjuje dokaze i utvrđuje činjenice. Pritom uzima u obzir činjenice utvrđene u postupku donošenja osporene odluke, kojima nije vezan, i činjenice koje je sam utvrdio. Stranke mogu predlagati koje činjenice treba utvrditi te dokaze kojima se one mogu utvrditi, ali sud nije vezan tim prijedlozima. Dokazi su isprave, saslušanje stranaka, iskaz svjedoka, mišljenje i nalaz vještaka, očevid i druga dokazna sredstva. Sud izvodi dokaze prema pravilima kojima je uređeno dokazivanje u parničnom postavku. ${ }^{16}$

12 Bayer, Kazneno procesno pravo, 173-177.

13 Carl-Friedrich Stuckenberg, „Schuldprinzip und Wahrheitsforschung: Bemerkungen zum Verhältnis von materiellem Recht und Prozessrecht", Goltdammer's Archiv für Strafrecht 163, (2016): 699 .

14 Boris Ljubanović, „Načelo traženja materijalne istine i upravni postupak“, Hrvatska komparativna i javna uprava 19, br. 4 (2019): 665.

15 Članak 58. stavci 1. i 3. Zakona o upravnim sporovima.

16 Članak 33. Zakona o upravnim sporovima. 
Sud u sporu odlučuje na temelju usmene, neposredne i javne rasprave. Bez održavanja rasprave može odlučiti samo u pet slučajeva propisanih Zakonom o upravnim sporovima. Među njima je i slučaj kada tužitelj osporava primjenu prava, činjenice su nesporne, a stranke u tužbi ili u odgovoru na tužbu izričito ne zahtijevaju održavanje rasprave, kao i slučaj kada se stranke o tome izrijekom suglase, a sud utvrdi da nije potrebno izvoditi nove dokaze. ${ }^{17}$

Ovaj je Zakon ujedno propisao kako protiv presude upravnog suda stranke mogu podnijeti žalbu i to zbog bitne povrede sudskoga postupka, pogrešno ili nepotpuno utvrđenoga činjeničnog stanja u sporu te pogrešne primjene materijalnog prava. Pri tome je isključio pravo osporavanja žalbom presude kojom je pojedinačna odluka javnopravnog tijela poništena ili oglašena ništavom i predmet je prvi put vraćen na ponovni postupak, kao i presude kojom je sud naložio donošenje pojedinačne odluke koja nije donesena u propisanom roku. Visoki upravni sud o žalbi odlučuje na sjednici vijeća bez održavanja rasprave, no raspravu može održati ako to smatra potrebnim. Pri tome se na zakazivanje i tijek rasprave na odgovarajući način primjenjuju odredbe o raspravi pred upravnim sudom. Visoki upravni sud obvezan je poništiti prvostupanjsku presudu te sam otkloniti nedostatke i presudom riješiti stvar, ako utvrdi da je upravni sud počinio bitnu povredu pravila sudskog postupka, pogrešno ili nepotpuno utvrdio činjenično stanje ili pogrešno primijenio materijalno pravo. ${ }^{18}$

Izložene odredbe Zakona o upravnim sporovima pravna teorija promatra afirmativno i optimistično. Koprić ističe: „Upravni će sudovi suditi temeljem usmene i kontradiktorne javne rasprave ne samo o zakonitosti nego i o činjeničnom stanju utvrđenom u upravnom postupku - upravni spor pune jurisdikcije postaje pravilo, a ne kao dosad apsolutna iznimka“. ${ }^{19}$ Đerđa i Pičuljan naglasili su: „Meritorno rješavanje upravnih stvari umjesto donošenja samo kasacijskih odluka značajno će ubrzati ostvarivanje prava građana u građanskim stvarima“". ${ }^{20}$ Maganić i Dika ustvrdili su: „Treba očekivati da odluke u kojima će upravni sudovi nadomještavati odluke javnopravnih tijela biti sve brojnije...".21

Međutim, tumačenje pravila Zakona o upravnim sporovima ipak ne ide u smjeru očekivane preferiranosti spora pune jurisdikcije. Tako je izišlo na vidjelo da upravni sudovi suviše široko i slobodno tumače neodređen izraz „priroda stvari“ sadržan u članku 58. stavci 1. i 3. Zakona. ${ }^{22}$ Time se ostvaruje predviđanje Koprića kako će

17 Članci 7. i 36. Zakona o upravnim sporovima.

18 Članak 66. stavak 1., članak 66.a, članak 73. stavci 2. i 3. i članak 74. stavak 2. Zakona o upravnim sporovima.

19 Ivan Koprić, „Europski standardi i modernizacija upravnog sudovanja u Hrvatskoj“, u: Europeizacija upravnog sudovanja u Hrvatskoj, ur. Ivan Koprić (Zagreb: Institut za javnu upravu, 2014.), 11.

20 Dario Đerđa i Zoran Pičuljan, „Nastanak i temeljni instituti novog Zakona o upravnim sporovima“", u: Europeizacija upravnog sudovanja u Hrvatskoj, ur. Ivan Koprić (Zagreb: Institut za javnu upravu, 2014.), 116.

21 Aleksandra Maganić i Mihajlo Dika, „Primjena odredaba parničnog postupka u upravnom sporu“", u: Novosti u upravnom pravu i upravnosudskoj praksi - Zbornik radova, ur. Ante Galić (Zagreb: Organizator, 2016.), 124.

22 Frane Staničić, Bosiljka Britvić-Vetma i Božidar Horvat, Komentar Zakona o upravnim sporovima (Zagreb: Narodne novine, 2017.), 193-194. 
upravni sudovi iskoristiti nejasni standard „prirode stvari“ i u velikoj mjeri vraćati predmete na rješavanje tuženim tijelima, a što nije u skladu sa svrhama reforme. ${ }^{23}$ Za očekivati je da će se značenje pojma „priroda stvari“ razjasniti u praksi upravnog sudovanja.

U prilog sporu pune jurisdikcije ne ide niti tumačenje kako sud može donijeti reformacijsku odluku samo ako se u tužbi, odnosno tužbenom zahtjevu to zatraži od njega. ${ }^{24}$ Ističe se stajalište kako sud ne može spor o zakonitosti samostalno pretvoriti u spor pune jurisdikcije. Stoga, ako tužitelj ne zahtijeva u tužbenom zahtjevu da sud samostalno riješi predmetni spor, stvar treba vratiti tijelu na ponovno postupanje. ${ }^{25}$ Jasno je da to shvaćanje proizlazi iz članka 31. stavka 1. Zakona o upravnim sporovima u skladu s kojim sud odlučuje u granicama tužbenog zahtjeva, ali nije vezan razlozima tužbe. Jednako tako proizlazi i iz članka 22. stavka 3. ovoga Zakona, prema kojemu u slučaju propisanom u stavku 2. točka 1. i 2. istoga članka, tužbom se može zahtijevati da sud odluči o pravu, obvezi ili pravnom interesu stranke. Potonjom se odredbom suprotno duhu reforme upravnog spora prednost daje sporu o zakonitosti, jer iz nje slijedi da ako u tužbi nema spomenutoga zahtjeva da sud riješi predmetni spor, riječ je o sporu o zakonitosti. Stoga bi valjalo članak 22. Zakona o upravnim sporovima izmijeniti na način da se stavak 3. uvrsti kao stavak 2. točka 5. U članku 29. Zakona dodatno bi valjalo propisati, da ako je nedostatak tužbe u tome što u njoj nije navedeno zahtijeva li se odluka u smislu točke 1. i 2 . ili točke 5. navedene odredbe, sud treba pozvati tužitelja da otkloni taj nedostatak u određenom roku.

Kako će se dalje u radu pokazati, pitanje prihvaćanja inkvizitornog ili istražnog načela u upravnom sporu u Hrvatskoj predmet je sporenja. Horvat zastupa mišljenje da u upravnom sporu vrijedi načelo stranačke, a ne načelo materijalne istine, kao i u parničnom postupku, jer u upravnom sporu sud ne utvrđuje činjenice po službenoj dužnosti. Od stranke se u upravnom sporu apsolutno traži aktivnost, a neaktivnost ide na njezinu štetu. Horvat ističe kako odredbe članka 33. Zakona o upravnim sporovima ne znače da sud provodi dokaze po službenoj dužnosti, niti one sudu u upravnom sporu daju oficiozni (istražni) karakter. ${ }^{26}$ I prema stajalištu Rajka, za razliku od javnopravnog tijela u upravnom postupku, sud u upravnom sporu nema obvezu utvrditi materijalnu istinu. On izlaže da u upravnom sporu ionako u pravilu ne dolazi do ponovnoga cjelovitog rješavanja upravne stvari (ispočetka), već do rješavanja spora između stranaka o zakonitosti osporavanog upravnog akta. Pritom razlozi ništavnosti pojedinačne odluke i ništetnosti upravnog ugovora na koje upravni sud pazi po službenoj dužnosti nisu niti vezani za utvrđivanje činjenica. Navodi kako ovlast suda da po službenoj dužnosti utvrđuje pojedine činjenice nije potpuno isključena. Tako primjerice, prema članku 34. stavak 3. Zakona o upravnim sporovima sud ima ovlast od stranke zatražiti da u primjerenom roku dostavi isprave i druge dokaze

23 Koprić, Europski standardi i modernizacija upravnog sudovanja u Hrvatskoj, 12.

24 Božidar Horvat, „Upravni spor od podnošenja tužbe do izvršenja - sporna pitanja u praksi“, Zbornik radova Pravnog fakulteta u Splitu 52, br. 1 (2015): 228.

25 Frane Staničić, Bosiljka Britvić-Vetma i Božidar Horvat, Komentar Zakona o upravnim sporovima, 113-114.

26 Horvat, Upravni spor od podnošenja tužbe do izvršenja - sporna pitanja u praksi, 227, 231232. 
koji se mogu koristiti u sporu, prema članku 35. stavak 1. ima ovlast zahtijevati da javnopravna tijela dostave isprave kojima raspolažu. Stoga je mišljenje Rajka da je u upravnom sporu riječ „o modificiranoj stranačkoj istini“ koja odgovara bitnim obilježjima upravnog spora. ${ }^{27}$ Maganić i Dika zastupaju mišljenje kako bi u upravnom sporu kada je riječ o utvrđivanju činjenica sud bio ovlašten utvrđivati činjenice koje stranke nisu iznijele kad god bi ocijenio da je radi osiguranja objektivne zakonitosti u suđenju vrijedilo pravilo utvrditi činjenično stanje..$^{28}$

Punu valjanost po našem mišljenju imaju stajališta Staničića. On naglašava kako u sporu pune jurisdikcije predmet spora više nije samo ocjena zakonitosti pojedinačne odluke, propuštanja donošenja pojedinačne odluke, postupanja, propuštanja postupanja odnosno sklapanja, raskidanja i izvršavanja upravnog ugovora, već je predmet spora, sukladno članku 58. stavku 1. Zakona o upravnim sporovima, rješavanje stvari. Budući da upravni sud rješava upravnu stvar on ne može zanemariti načelo materijalne istine koje bi javnopravno tijelo bilo obvezno primijeniti. Ne mogu za istu upravnu stvar vrijediti različita pravila u njezinom rješavanju. U upravnom sporu, upozorava Staničić, primarno se štite subjektivna prava stranaka, ali se štiti i objektivna zakonitost. Ne smijemo zaboraviti obvezu suda da brine o javnom interesu. Prema ovom autoru „moglo bi se utvrditi da je sud i dužan ex offo utvrđivati činjenice“. On razlaže da prema članku 33. stavka 1. Zakona o upravnim sporovima sud slobodno ocjenjuje dokaze i utvrđuje činjenice. Prema stavku 2. istoga članka sud uzima u obzir činjenice koje je sam utvrdio, a prema stavku 3. sud nije vezan prijedlozima stranaka o činjenicama koje treba utvrditi i dokazima kojima se one trebaju utvrditi. Zato se jednako validno može ustvrditi da sud ima pravo, ali i obvezu, utvrđivati činjenice po službenoj dužnosti bez obzira na to što stranke nisu u tužbenom zahtjevu i/ili odgovoru na tužbu istaknule, odnosno predložile njihovo utvrđivanje, što bi posebno moralo vrijediti u sporovima pune jurisdikcije. ${ }^{29}$

\section{MOGUĆNOST UTVR円IVANJA ISTINE U UPRAVNOM POSTUPKU I UPRAVNOM SPORU}

\subsection{Upravni postupak}

U suglasju s istražnim i oficijelnim načelom koji su prihvaćeni u Zakonu o općem upravnom postupku, službena osoba u upravnom postupku ima snažne istražne ovlasti:

1) utvrđuje sve činjenice i okolnosti bitne za rješavanje o upravnoj stvari, ${ }^{30}$

2) određuje izvođenje dokaza kad nađe da je to potrebno radi razjašnjenja stvari te upotpunjuje činjenično stanje i izvodi dokaze o činjenicama koje nisu bile iznesene prije u postupku ili još nisu utvrđene, a potrebne su radi

27 Alen Rajko, „Teret dokazivanja u upravnom postupku i upravnom sporu“, u: Novosti u upravnom pravu i upravnosudskoj praksi - Zbornik radova, ur. Ante Galić (Zagreb: Organizator, 2016.), 101-102.

28 Maganić, Dika, Primjena odredaba parničnog postupka u upravnom sporu, 132.

29 Staničić u: Staničić, Britvić-Vetma, Horvat, Komentar Zakona o upravnim sporovima, 125-126.

30 Članak 47. stavak 1. Zakona o općem upravnom postupku, Narodne novine, br. 47/09. 
utvrđivanja pravnog stanja stvari ${ }^{31} \mathrm{i}$

3) utvrđuje činjenično stanje svim sredstvima prikladnim za dokazivanje te u tu svrhu može pribaviti isprave, saslušati svjedoke, pribaviti nalaz i mišljenje vještaka, postavljati pitanja vještaku i tražiti objašnjenja o izloženom nalazu i mišljenju te obaviti očevid. ${ }^{32}$

Načelo traženja materijalne istine utemeljeno je u i drugim pravilima Zakona o općem upravnom postupku. U postupku treba utvrditi pravo stanje stvari i u tu se svrhu moraju utvrditi sve činjenice i okolnosti koje su bitne za zakonito i pravilno rješavanje upravnih stvari. Službena osoba slobodno ocjenjuje dokaze. Rješenje se može pobijati žalbom zbog pogrešnog ili nepotpunog utvrđenog činjeničnog stanja. U žalbenom postupku dopušteno je iznošenje novih činjenica i novih dokaza, s tim da je stranka dužna obrazložiti zašto te činjenice i dokaze nije iznijela tijekom prvostupanjskog postupka. Dopušteno je podnijeti prijedlog za obnovu postupka ako se sazna za nove činjenice ili stekne mogućnost da se upotrijebe novi dokazi koji bi sami ili u vezi s već izvedenim i upotrijebljenim dokazima mogli dovesti do drukčijeg rješenja da su te činjenice, odnosno dokazi bili izneseni, odnosno upotrijebljeni u prijašnjem postupku. ${ }^{33}$

S druge strane, načelo traženja materijalne istine ograničavaju osobito sljedeća pravila Zakona o općem upravnom postupku: upravna stvar može se neposredno riješiti bez provedbe ispitnog postupka na temelju činjenica koje su učinjene vjerojatnima i činjenica ili okolnosti koje nisu potpuno dokazane; upravna stvar u potpunosti ili o pojedinim spornim pitanjima može se riješiti nagodbom; te drugostupanjsko tijelo ne može izmijeniti prvostupanjsko rješenje na štetu stranke koja je izjavila žalbu. ${ }^{34}$

\subsection{Upravni spor}

Za razliku od ranije važećega Zakona o upravnim sporovima iz 1991., koji je propisivao da se u upravnim sporovima na odgovarajući način primjenjuju odredbe Zakona o parničnom postupku, ${ }^{35}$ važeći Zakon o upravnim sporovima određuje da dokaze sud izvodi prema pravilima kojima je uređeno dokazivanje u parničnom postupku. ${ }^{36} \mathrm{U}$ parničnom postupku prevladava raspravno načelo. Stranke su dužne najkasnije na pripremnom ročištu iznijeti činjenice i predložiti dokaze na kojima temelje svoje zahtjeve ili pobijaju navode i dokaze protivnih stranaka. Sud je ovlašten utvrditi činjenice koje stranke nisu iznijele i izvesti dokaze koje stranke nisu predložile samo ako posumnja da stranke idu za tim da raspolažu zahtjevima kojima ne mogu raspolagati, ako zakonom nije drukčije određeno. ${ }^{37}$ Sud može do zaključenja

31 Članak 51. stavak 2. Zakona o općem upravnom postupku, Narodne novine, br. 47/09.

32 Članak 58. stavak 1. Zakona o općem upravnom postupku, Narodne novine, br. 47/09.

33 Članak 8., članak 9., članak 108. stavci 1. i 2. i članak 123. stavak 1. Zakona o općem upravnom postupku.

34 Članak 49. točka 2., članak 50. točka 2., članak 57., članak 118. stavak 1. Zakona o općem upravnom postupku.

35 Članka 60. ranije važećega Zakona o upravnim sporovima.

36 Članak 33. stavak 5. Zakona o upravnim sporovima.

37 Članak 7. stavci 1. i 2. i članak 219. stavak 1. Zakona o parničnom postupku, Službeni list SFRJ, br. 4/77., 36/77., 36/80., 6/80., 69/82., 43/82., 58/84., 74/87., 57/89., 20/90., 27/90., 
prethodnog postupka, kada ocijeni da je to svrsishodno za pravilno rješenje spora, upozoriti stranke na njihovu dužnost iznošenja činjenica i predlaganja dokaza na kojima temelje svoj zahtjev ili pobijaju navode i dokaze protivnih stranaka, a osobito na potrebu iznošenja odlučnih činjenica i predlaganja određenih dokaza te iznijeti razloge zbog kojih smatra da je to potrebno. ${ }^{38}$

Vezanost suda za volju stranaka u odnosu na činjenice kojemu je dopušteno utvrđivati i dokaze koje smije izvoditi bitno ograničava načelo traženja materijalne istine. Stoga se može prihvatiti stajalište kako je u parničnom postupku prihvaćena stranačka, a ne materijalna istina.

Metodu postupanja kojom se utvrđuju činjenice u parničnom postupku, osim one koja se odnosi na izvođenje dokaza, Zakon o upravnim sporovima, po mišljenju autora, nije prihvatio iz više razloga. Prvo, proširen je predmet upravnog spora upravni sudovi ne sude kao ranije jedino o zakonitosti, već i o činjeničnom stanju utvrđenom u upravnom postupku (spor pune jurisdikcije). Drugo, neprihvatljivo je da u rješavanju jednih te istih upravnih stvari u upravnom sporu vrijedi metoda postupanja kojom sud utvrđuje činjenice s manjim stupnjem izvjesnosti (stranačka istina) nego što ih je u prethodnom upravnom postupku utvrdilo javnopravno tijelo (materijalna istina). Treće, bez utvrđivanja istine nema ni pravilne i zakonite konkluzije, presude kojom se regulira sporni pravni odnos i štiti javni poredak. Konačno, četvrto, cilj je upravnog spora osigurati zakonitost i sudsku zaštitu prava i pravnih interesa fizičkih i pravnih osoba i drugih stranaka povrijeđenih pojedinačnim odlukama ili postupanjem javnopravnih tijela. ${ }^{39}$

Prema svemu naznačenom, važeći Zakon o upravnim sporovima s razlogom nije zadržao procesni sustav Zakona o parničnom postupku u kojem prevladava raspravno načelo, već je prihvatio procesni sustav osnovan na kombinaciji raspravnog i istražnog načela. Zadatak je suda da ta načela kao „opće norme visokog ranga“ usklađeno primjenjuje. ${ }^{40}$ Istražna ovlaštenja suda, kojima najviše dolazi do izražaja načelo traženja materijalne istine, proizlaze iz sljedećih pravila Zakona o upravnim sporovima:

1) Sud slobodno utvrđuje činjenice. ${ }^{41}$ To znači da sud slobodno, što znači na slobodan način, bez zabrane, bez ograničenja utvrđuje činjenice i izvodi dokaze prema svojim spoznajnim potrebama. ${ }^{42}$

2) Sud uzima u obzir i činjenice koje je sam utvrdio. ${ }^{43}$

3) Sud može od stranke zatražiti da u primjerenom roku dostavi isprave i druge

35/91. i Narodne novine, br. 53/91., 91/92., 112/99., 129/00., 88/01., 117/03., 88/05., 2/07., 96/08., 84/08., 123/08., 57/11., 148/11. - službeni pročišćeni tekst, 25/13., 89/14., 70/19.

38 Članak 219. stavak 2. Zakona o parničnom postupku.

39 Vidi članak 2. stavak 1. Zakona o upravnim sporovima. Kako se sudska kontrola uprave provodi radi zaštite prava građana, ali i zaštite javnog interesa i objektivnog pravnog poretka smatra i Woehrling. Vidi Jean-Marie Woehrling, ,Judicial Control of Administrative Authorities in Europe: Toward a Common Model“, Hrvatska javna uprava 6, br. 3. (2006): 36.

40 Krapac, Kazneno procesno pravo, 86.

41 Članak 33. stavak 1. Zakona o upravnim sporovima.

42 Vladimir Anić, Rječnik hrvatskoga jezika (Zagreb: Novi liber, 1994.), 956.

43 Članak 33. stavak 2. Zakona o upravnim sporovima. 
dokaze koji se mogu koristiti u sporu. ${ }^{44}$

4) Sud može zahtijevati da mu javnopravna tijela dostave isprave kojima raspolažu. ${ }^{45}$

5) Sud može utvrditi da je potrebno izvoditi nove dokaze, iako su se stranke izrijekom suglasile da se spor riješi bez rasprave. ${ }^{46}$

6) Sud može postavljati pitanja svjedoku radi provjere, dopune ili razjašnjenja, postavljati pitanja vještaku i prema potrebi traži objašnjenja u vezi s danim nalazom i mišljenjem. ${ }^{47}$

Nužno je naglasiti da istražne ovlasti suca mogu negativno utjecati na njegovu objektivnost. No, prema rezultatima istraživanja, koje je proveo Mrčela, ta opasnost u sudačkoj praksi nije izražena. U analiziranoj praksi u samo je jednom predmetu došlo do ukidanja presude zbog nepravilnoga korištenja dokaznih ovlasti raspravnog suca, dok je u tri predmeta do ukidanja presude došlo jer je raspravni sudac nekvalitetno proveo ispitivanje okrivljenika i svjedoka. ${ }^{48}$ Prema Damaškinom mišljenju, dužnost suca da prema istražnom načelu na raspravi sudjeluje u utvrđivanju činjenica (prikupljanju i izvođenju dokaza) ne treba dovoditi u pitanje. Pasivni položaj suca bez sumnje bi išao u prilog njegovoj neutralnosti, ali bi takav položaj mogao negativno utjecati na traženje istine. ${ }^{49} \mathrm{U}$ konačnici, za utvrđivanje istine mora biti odgovoran sud, a ne stranke koje u procesu ponajprije slijede vlastite interese, koji se ne moraju poklapati s istraživanjem stvarnoga činjeničnog stanja. ${ }^{50}$

Načelo traženja materijalne istine dolazi do izražaja i u drugim pravilima Zakona o upravnim sporovima. Sud slobodno ocjenjuje dokaze ${ }^{51}$ Rasprava se zaključuje kada sud ocijeni da je u predmetu dovoljno raspravljeno da se može donijeti presuda, a rasprava se može ponovno otvoriti ako je to potrebno radi razjašnjenja pojedinih važnih pitanja. ${ }^{52}$ Sud donosi presudu prema slobodnom uvjerenju. ${ }^{53}$ Presuda se može temeljiti samo na činjenicama i dokazima u kojima je strankama dana mogućnost izjašnjavanja. ${ }^{54}$ Žalba se može izjaviti zbog pogrešno ili nepotpuno utvrđenog stanja u sporu..$^{55}$ Visoki upravni sud će poništiti prvostupanjsku presudu te će sam otkloniti nedostatke i presudom riješiti stvar ako utvrdi da je upravni sud pogrešno ili

44 Članak 34. stavak 3. Zakona o upravnim sporovima.

45 Članak 35. stavak 1. Zakona o upravnim sporovima.

46 Članak 36. točka 5. Zakona o upravnim sporovima.

47 Članak 33. stavak 5. Zakona o upravnim sporovima te članak 244. stavak 1. i članak 259. stavak 1. Zakona o parničnom postupku.

48 Marin Mrčela, Kazneni postupak - upravljanje glavnom raspravom (Zagreb: Informator, 2000.), 122-123.

49 Mirijan Damaška, „Epistemology and legal regulation of proof“, Law, Probability \& Risk 2, br. 2 (2003): 121.

50 Maciej Małolepszy, „Abschied von der Suche nach der Wahrheit im deutschen und polnischen Strafverfahren: Eine parallele Tendenz?“, Zeitschrift für die gesamte Strafrechtswissenschaft 126, br. 2 (2014): 505-506.

51 Članak 33. stavak 1. Zakona o upravnim sporovima.

52 Članak 39. stavak 3. Zakona o upravnim sporovima.

53 Članak 55. stavak 3. Zakona o upravnim sporovima.

54 Članak 55. stavak 4. Zakona o upravnim sporovima.

55 Članak 66. stavak 1. Zakona o upravnim sporovima. 
nepotpuno utvrdio činjenično stanje.${ }^{56}$ Konačno, spor okončan presudom obnovit će se na prijedlog stranke, ako ona sazna za nove činjenice ili nađe ili stekne mogućnost da upotrijebi nove dokaze kojima bi spor bio povoljnije riješen za nju da su te činjenice, odnosno dokazi bili izneseni ili upotrijebljeni u prijašnjem sudskom postupku. ${ }^{57}$

$\mathrm{S}$ druge strane, neka pravila Zakona o upravnim sporovima ograničavaju načelo traženja materijalne istine iz razloga koji su važniji od interesa saznanja istine. Tako se, npr. u žalbi ne mogu iznositi nove činjenice..$^{58}$ Žalba nije dopuštena protiv presude kojom je pojedinačna odluka javnopravnog tijela poništena ili oglašena ništavom i predmet prvi put vraćen na ponovni postupak, kao ni protiv presude kojom je sud naložio donošenje pojedinačne odluke koja nije donesena u propisanom roku. ${ }^{59}$ Stranke mogu tijekom spora pred sudom sklopiti nagodbu o predmetu spora. ${ }^{60}$

\subsection{Konačna ocjena o mogućnostima utvrđivanja istine o činjenicama u upravnom postupku $i$ upravnom sporu}

$\mathrm{U}$ skladu s istražnim načelom koje vlada u upravnom postupku, pravila toga postupka daju službenoj osobi javnopravnog tijela snažne istražne ovlasti. Ta i druga pravila kojima je utemeljeno načelo traženja materijalne istine u upravnom postupku (vidi u poglavlju 4.1.) pružaju javnopravnom tijelu mogućnost da s najvećim mogućim stupnjem izvjesnosti utvrđuje postojanje ili nepostojanje činjenica, tj. materijalnu istinu.

Upravni je spor osnovan na prepletanju raspravnog i istražnog načela koji čine cjelinu. Pravila toga spora iz kojih proizlaze bitna istražna ovlaštenja suda, kao i druga pravila kojima dolazi do izražaja načelo traženja materijalne istine u upravnom sporu (vidi u poglavlju 4.2.) omogućuju sudu da s jednakim stupnjem izvjesnosti, kao i javnopravno tijelo u upravnom postupku, utvrđuje materijalnu istinu, uz uvjet da koristi svoje istražne ovlasti uvijek kada ocijeni da je to potrebno radi traženja istine. Ne treba se bojati, prema rezultatima provedenoga istraživanja, da bi suci mogli zloupotrijebiti svoje istražne ovlasti.

\section{ZAKLJUČAK}

Načelo traženja materijalne istine prihvaćeno je u onim procesnim sustavima u kojima dolazi do izražaja ponajprije inkvizitorno ili istražno načelo, prema kojem procesno tijelo ima pravo na vlastitu inicijativu, neovisno o prijedlogu stranaka, utvrđivati činjenice i izvoditi dokaze.

Zakon o općem upravnom postupku sustav je procesnih normi koji je osnovan na istražnom načelu i u skladu s tim načelom na jakim istražnim ovlastima javnopravnoga tijela. Procesni sustav Zakona o upravnim sporovima teži skladnoj kombinaciji raspravnog i istražnog načela u kojoj sud ima izravne istražne ovlasti.

56 Članak 74. stavak 2. Zakona o upravnim sporovima.

57 Članak 76. stavak 1. točka 6. Zakona o upravnim sporovima.

58 Članak 69. stavak 3. Zakona o upravnim sporovima.

59 Članak 66.a stavak 1. Zakona o upravnim sporovima.

60 Članak 89. stavak 1. Zakona o upravnim sporovima. 
Metoda postupanja prihvaćena u upravnom sporu sudu pruža mogućnost utvrđivanja istine o činjenicama s jednakim stupnjem izvjesnosti koju može dostići javnopravno tijelo propisanom metodom postupanja u upravnom postupku.

Sud će dostići jednaku izvjesnost u utvrđivanju činjeničnog stanja uz pretpostavku da se služi svojim istražnim ovlastima kada god ocijeni da je to potrebno radi istinita (pravilna) utvrđenja činjeničnog stanja na kojem legitimno utemeljuje svoju presudu. Ujedno, u tu svrhu treba tumačiti pravila Zakona o upravnim sporovima prema cilju toga zakona, dakle teleološki, slijedom čega će spor pune jurisdikcije i u praksi, a ne jedino ad normam, doći do punog izražaja.

Prema rezultatima istraživanja sudske prakse, istražne ovlasti raspravnih sudaca ne ugrožavaju njihov nepristrani odnos prema suprotstavljenim stranama.

\section{LITERATURA}

1. Anić, Vladimir. Rječnik hrvatskoga jezika. Zagreb: Novi liber, 1994.

2. Bajović, Vanja. O činjenicama i istini u krivičnom postupku. Beograd: Pravni fakultet, 2015.

3. Bayer, Vladimir. Kazneno procesno pravo: odabrana poglavlja, Knjiga I. Uvod u teoriju kaznenog procesnog prava. Zagreb: Ministarstvo unutarnjih poslova, 1995.

4. Damaška, Mirijan. „Epistemology and legal regulation of proof“. Law, Probability \& Risk 2, br. 2 (2003): 117-130.

5. Đerđa, Dario. Upravni spor. Rijeka: Pravni fakultet, 2017.

6. Đerđa, Dario i Zoran Pičuljan. „Nastanak i temeljni instituti novog Zakona o upravnim sporovima. U: Europeizacija upravnog sudovanja u Hrvatskoj, ur. Ivan Koprić, 93-122. Zagreb: Institut za javnu upravu, 2014.

7. Horvat, Božidar. „Upravni spor od podnošenja tužbe do izvršenja - sporna pitanja u praksi“. Zbornik radova Pravnog fakulteta u Splitu 52, br. 1 (2015): 223-242.

8. Koprić, Ivan. „Europski standardi i modernizacija upravnog sudovanja u Hrvatskoj“. U: Europeizacija upravnog sudovanja u Hrvatskoj, ur. Ivan Koprić, 1-20. Zagreb: Institut za javnu upravu, 2014.

9. Krapac, Davor, Zlata Đurđević, Elizabeta Ivičević Karas, Marin Bonačić i Zoran Burić. Kazneno procesno pravo. Prva knjiga: Institucije. Zagreb: Narodne novine, 2020.

10. Ljubanović, Boris. „Načelo traženja materijalne istine i upravni postupak“. Hrvatska komparativna i javna uprava 19, br. 4 (2019): 659-675.

11. Maganić, Aleksandra i Mihajlo Dika. „Primjena odredaba parničnog postupka u upravnom sporu“. U: Novosti u upravnom pravu i upravnosudskoj praksi-Zbornik radova, ur. Ante Galić, 113-133. Zagreb: Organizator, 2016.

12. Małolepszy, Maciej. „Abschied von der Suche nach der Wahrheit im deutschen und polnischen Strafverfahren: Eine parallele Tendenz?". Zeitschrift für die gesamte Strafrechtswissenschaft 126, br. 2 (2014): 498-508.

13. Marshal, Geoffrey. „Provisional Concept and Definitions of Fact“. Law and philosophy 18, br. 5 (1999): 447-460.

14. Mrčela, Marin. Kazneni postupak-upravljanje glavnom raspravom. Zagreb: Informator, 2000.

15. Rajko, Alen. „Teret dokazivanja u upravnom postupku i upravnom sporu“. U: Novosti u upravnom pravu i upravnosudskoj praksi - Zbornik radova, ur. Ante Galić, 61-111. Zagreb: Organizator, 2016.

16. Staničić, Frane, Bosiljka Britvić-Vetma i Božidar Horvat. Komentar Zakona o upravnim sporovima. Zagreb: Narodne novine, 2017. 
17. Stuckenberg, Carl-Friedrich. „Schuldprinzip und Wahrheitsforschung: Bemerkungen zum Verhältnis von materiellem Recht und Prozessrecht". Goltdammer 's Archiv für Strafrecht 163, (2016): 689-701.

18. Šešić, Bogdan. Logika i naučna metodologija. Beograd: Naučna knjiga, 1962.

19. Triva, Siniša i Mihajlo Dika. Građansko parnično procesno pravo. Zagreb: Narodne novine, 2004.

20. Vodinelić, Vladimir. „Problematika činjenica u dokaznoj teoriji krivičnog procesnog prava“. Anali Pravnog fakulteta u Beogradu 40, br. 5 (1992): 369-388.

21. Woehrling, Jean-Marie. „Judicial Control of Administrative Authorities in Europe: Toward a Common Model“. Hrvatska javna uprava 6, br. 3 (2006): 35-56.

22. Zakon o općem upravnom postupku, Narodne novine, br. 47/09.

23. Zakon o parničnom postupku, Službeni list SFRJ, br. 4/77., 36/77., 36/80., 6/80., 69/82., 43/82., 58/84., 74/87., 57/89., 20/90., 27/90., 35/91. i Narodne novine, br. 53/91., 91/92., 112/99., 129/00., 88/01., 117/03., 88/05., 2/07., 96/08., 84/08., 123/08., 57/11., 148/11. službeni pročišćeni tekst, 25/13., 89/14., 70/19.

24. Zakon o upravnim sporovima, Narodne novine, br. 20/10., 143/12., 152/14., 94/16., 29/17.

25. Zakon o upravnim sporovima, Službeni list SFRJ, br. 4/77., 36/77. i Narodne novine, br. 53/91., 9/92., 77/92., 20/10. 


\title{
Boris Ljubanović* \\ Dario Đerđa**
}

\author{
Summary
}

\section{PROCEDURAL METHOD IN ADMINISTRATIVE PROCEEDINGS IN RELATION TO THE PROCEDURAL METHOD IN AN ADMINISTRATIVE DISPUTE AND COGNITION OF THE TRUTH ABOUT FACTS}

The paper deals with the methods of seeking the truth in an administrative procedure and administrative dispute. The introductory part emphasizes the task of legal doctrine to interpret the rules of the Administrative Dispute Act on fact-finding and proving, and raises the question of whether the procedural method of establishing facts in an administrative dispute provides the judge with the possibility of determining the truth. It addresses the conceptual determination of facts, factual situation, proving, establishing facts, and the principle of searching for material truth. This is followed by a discussion of the rules on the dispute of full jurisdiction from the Administrative Dispute Act and the interpretation of these rules in scientific and professional papers. At the same time, methods that seek to determine the facts in administrative procedures and administrative disputes are compared. In conclusion, the authors summarize the results of the analysis, emphasizing thereby that the General Administrative Procedure Act is a set of procedural norms based on the investigative principle and which, in accordance with this principle, provides the public law authority with strong investigative powers. The procedural system of the Administrative Dispute Act strives for a harmonious combination of the principle of deliberation and investigation in which the court has direct investigative powers. The procedure method accepted in an administrative dispute provides the court with the possibility of establishing the truth about facts with the same degree of certainty that a public law authority can achieve with the prescribed method in administrative procedures.

Keywords: factual situation; establishing facts; material truth; administrative dispute; administrative procedure.

* Boris Ljubanović, Ph.D., Full Professor, Faculty of Law, University J.J. Strossmayer of Osijek; ljboris@pravos.hr. ORCID: https://orcid.org/0000-0003-3995-9991.

** Dario Đerđa, Ph.D., Full Professor, University of Rijeka, Faculty of Law; dariod@pravri.hr. ORCID: https://orcid.org/0000-0002-1095-1155. 